\title{
The Impact of Saving and Financial Development on Economic Growth in Turkey
}

\author{
Dr. Hatem Hatef Abdulkadhim Altaee \\ Head of Accounting Department \\ Cihan University, Sulaimani Camp \\ Sulaimaniyah-Kurdistan Region, Iraq \\ Tel: 964-771-423-1853Ｅ-mail: hatm.hatf@sulicihan.edu.krd \\ Dr. Mohamed Khaled Al-Jafari (Corresponding author) \\ Head of the Accounting and Finance Department \\ Prince Mohammad Bin Fahd University \\ Al Khobar, Kingdom of Saudi Arabia \\ Tel: 966-530052740Ｅ-mail: aljafarimohamedkhaled@yahoo.com
}

Received: August 5, 2019 Accepted: Oct. 21, 2019 Published: December 1, 2019

doi:10.5296/ajfa.v11i2.15481 URL: https://doi.org/10.5296/ajfa.v11i2.15481

\begin{abstract}
Since saving and financial development are vital to economic growth, this research empirically investigates the impact of saving and financial development on economic growth in Turkey. Therefore, a time series data from 1968 until 2017 were tested utilizing both the error correction model (ECM) and the autoregressive distributed lag approach (ARDL). The findings reveal an existence of a short-run and a long-run positive and significant effect of savings and financial development on economic growth. Conventional inputs such as capital and labor proved to be the most important factors in achieving economic growth in Turkey. The study concludes that an appropriate policy mix will enhance domestic saving in the country.
\end{abstract}

Keywords: Saving, Financial development, Economic growth, ARDL, Turkey

JEL Classification: C22, C32, O11, O16, O40 


\section{Introduction}

A growing body of theoretical and empirical work would push even skeptics toward the belief that saving and financial development are crucial to economic growth. However and despite the large number of scientific research on economic growth and the financial development of the Turkish economy, there is still a need to examine empirically the relationship between saving and the development of the financial sector on the one hand and economic growth on the other hand, for a longer period of time.

Saving from the point of view of economic intellectuals is an important requirement for economic growth (Lewis, 1955; Solow, 1956; Romer, 1986; Lucas, 1988). At the same time, many quantitative studies have concluded that gross domestic saving rate boosts investment rate and this higher investment rate in turn influences economic growth.

As mentioned earlier, there is no shortages in literature (Demirhan, 2016; Yildiz and Atasaygin, 2015; Zeran and Akbas, 2013; Şamiloğlu and Savaş, 2010) that studied the influences of different economic variables on economic growth in Turkey. However, results were always mixed and ambiguous, and this may be due in part to the sample size or to the period that previous studies covered. To avoid such an issue, this study used a larger sample size that covers the period for the past fifty years to investigate the effect of savings and financial developments on growth in the Republic of Turkey. Another important incentive to undertake this study, we strongly believe that low domestic saving rate in Turkey might be a constraint placed on its ability to achieve a rapid economic growth and worthwhile to investigate.

This paper is organized into the following sections: Section 2 sheds some lights on major macroeconomic facts that are related to the Turkish economy for the past fifty years. On the other hand, section 3 displays pertinent previous literatures. Section 4 introduces the data and illustrates the empirical methods that were used, while section 5 discusses thoroughly the empirical findings. The concluding remarks and recommendations are presented in section 6 .

\section{An Overview of Major Macroeconomic Indicators in Turkey}

Turkey is one of the MINT countries (Mexico, Indonesia, Nigeria and Turkey) that were listed to be the world's next big emerging economies after the BRICS (Brazil, Russia, India, China, and South Africa). It is one of the world's top 20 economies. In fact, it ranks 18 among the 20 most developed countries according to World Bank classification (World Development Indicators, 2018).

Accordingly, selected macroeconomic data on Turkey's economy in an indexed form with base year 1968 are depicted in Figure 1. The graph shows that the general trend in all of the variables have been upwards since 2001, with variations varying in intensity from one variable to another. Turkey's real GDP grew at an average annual rate of $4.2 \%$ over the entire period. This was higher than the global growth average of the last 3 years and nearly 3 
percentage points more than the average growth accomplished by emerging markets and developing economies. However, the rate of growth varied from time to time. In fact, from the year 2000 to 2017 Turkey's GDP growth rate averaged 4.2 percent but this figure climbed to 5.63 percent during the period ranging from 2010 to 2017. Similarly, the intensity of the variation of the rest of the variables varied as well. For instance, there is a high variation in saving, capital and financial development. However, GDP and labor variables showed almost a stable trend with low variation.

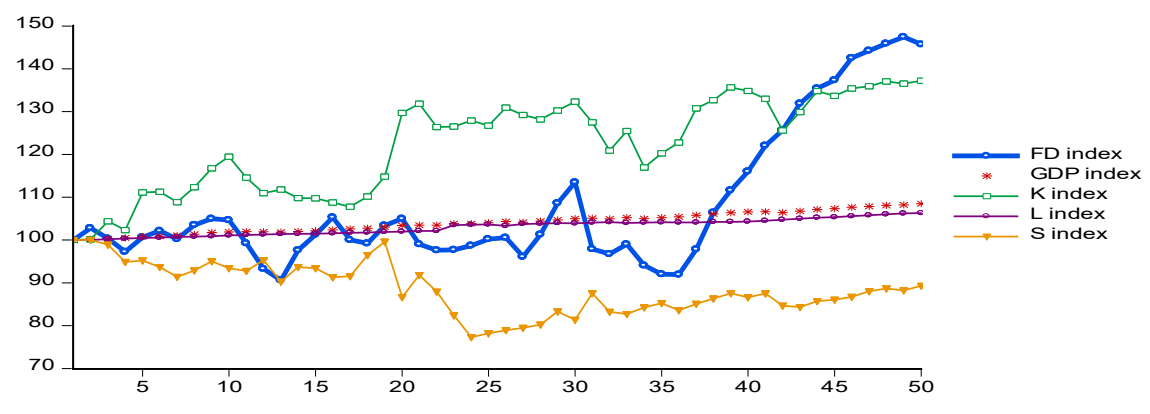

Figure 1. Trends of index of real GDP, capital (K), labor (L), financial development (FD), and saving $(\mathrm{S}),(1968=100)$

In addition, Figure 1 shows that gross domestic saving as a percentage of GDP has declined from an average of 38 percent in 1968 to an average of slightly less than $17 \%$ in the year of 1991. Indeed, this rate has been declining by around -0.09 percent throughout the entire period. However, since 2004, it started picking up and was reported at $26.4 \%$ in 2017 . On the other hand, growth of financial development was very considerable, especially in the years that followed the year 2002. Labor input growth trend has been consistent with the GDP movement.

For the purpose of comparing the Turkish economy with those of MINT countries, the gross domestic savings as a percentage of GDP, and the economic growth rates in those countries are presented in Table1.

From the figures in Table 1, it is clear that the Turkish gross domestic saving during the period 1981 to 2017 was almost the lowest in comparison with the rest of the countries in the bloc, and currently is considered low in international comparison. Nigeria, for example, enjoyed an aggregate savings rate averaged to $43.3 \%$. This ratio associated with a growth rate of GDP equals to 4.4 percent (World Development Indicators, 2018). 
Table 1. GDP Growth and Average of Gross Domestic Saving (\% of GDP) in MINT

Countries (1981-2017)

\begin{tabular}{|l|l|l|l|l|}
\hline RATI 0/RATE & TURKEY & MEXIC O & IN D O N ES IA & N I GERIA \\
\hline Growth Rate of GDP & 4.33 & 2.41 & 4.64 & 4.39 \\
\hline Average Ratio of GDS (\% of GDP) & 24.04 & 23.7 & 29.1 & 43.3 \\
\hline
\end{tabular}

Source: World Development Indicators (WDI), 2018. The World Bank Group

Similarly, Indonesia has achieved a growth rate of $4.64 \%$ in its gross domestic product with a ratio of domestic saving to GDP around 29.1\%. On the other hand, Mexico, had the lowest percentage of gross domestic saving and average growth rate of GDP among the MINT countries. They amounted to $23.7 \%$ and $2.41 \%$ respectively. The previous comparisons have led us to think that there is a relationship between saving and growth. The lower the saving rate in the economy, the lower the growth rate will be and this was applicable to Turkey as well. Therefore, we found this relationship to be intriguing enough to warrant further investigation.

\section{Literature Review}

This section presents previous literatures that studied the influences of different economic variables on economic growth in Turkey, and displayed in a descending chronological order.

Starting with the most recent study by Demirhan (2016) who tested the relationship between financial development and investment amount in Turkey. The author utilized the TodaYamamoto method on a sample that covers the first quarter of 1990 until the second quarter of 2015. The results revealed a uni-directional causality from stock market development to investment amount, and a uni-directional causality from investment amount to banking sector development. In addition, the findings revealed a bi-directional causality between banking sector development and stock market development, concluding that there is indirectly causality from banking sector development to investment amount, which will lead ultimately to a higher economic growth rate.

On the other hand, Yildiz and Atasaygin (2015) examined the relationship between financial deepening and economic growth in Turkey. The results of the ECM approach to cointegration revealed a long-run relationship between financial development and economic growth and that the demand-pulling hypothesis is valid for the Turkish economy.

Similarly, Güngör, Çiftçioğlu, and Balcılar (2014) investigated the causality between financial development and private savings using the bounds tests. The results show that private savings had a positive and significant impact on financial development. In addition, inflation rate found to have a negative but insignificant effect on savings. On the other hand, the variable of per capita disposable income found to have a positive and significant impact on private savings.

In addition, Zeran and Akbas (2013) empirically tested the savings-growth nexus in Turkey utilizing several econometric techniques to include bootstrap, process-based, Toda-Yamamoto, and linear Granger causality test. The results showed a bi-directional causality between saving and economic growth providing evidence supporting the feedback hypothesis. The study concluded that domestic saving increases investment and eventually has a positive effect on 
economic growth. Moreover, economic and political stability is a must requirement to create a suitable environment for investment.

Further, Şamiloğlu and Savaş (2010) investigated the effect of financial development on economic growth in Turkey utilizing the ARDL bounds testing approach. The study concluded that financial development is a long-run process stimulated by economic prosperity. On the other hand, domestic credit provided by the banking sector influenced economic growth in Turkey. The results of the Granger causality tests provided evidence supporting the supplyleading hypothesis in the long-run, and both the supply-leading and the demand-following hypotheses in the short-run.

Correspondingly, Yucel (2009) studied the relationship between financial development, trade openness and economic growth in Turkey. The author utilized several econometric methods to test the data to include: The Augmented Dickey-Fuller (ADF) unit root test, Johansen and Juselius (JJ) for cointegration test and Granger causality test. The results showed a positive and statistically significant effect between trade openness and economic growth and a significant negative impact between financial development and economic growth. The findings revealed also a bi-causal relationship between trade openness, financial development and economic growth.

Finally, Ardic and Damar (2006) examined the effects of financial sector deepening on economic growth in Turkey between 1996 and 2001. Contrary to the results of previous researches, the study found a strong negative relationship between financial deepening and economic growth. The authors concluded that financial development does not always contribute to economic growth.

\section{Data and Econometric Methods}

The savings-growth nexus is a topical issue in current growth literature. Levine (1991) explains what the financial system does and how it affects, and is affected by economic growth. Therefore, this study aims to examine the relationship between gross domestic savings, financial development and economic growth in Turkey for a period spanning from 1968 to 2017. The ARDL model or bounds testing approach as in Pesaran and Shin (1998), is employed to examine empirically the existence of short-and long-run relationship.

This approach is preferred to other approaches for several reasons. First, it can capture both long-run and short-run effect of saving and financial development on economic growth with other control variables. Second, this approach allows the variables of the model to possess a mixed order of integration, but none of them are I(2). Third, the ARDL method is more appropriate for a small size sample, and finally, this technique can eradicate the endogeneity problems existing in the model (Pesaran et al. 2001; Narayan, 2005).

\subsection{Data Selection and Variables}

An annual data from 1968 to 2017 were collected from two main sources: World Bank and Penn World Tables. Data related to variables of economic growth, capital, saving and financial developments were obtained from World Bank, World Development Indicators 
(http://microdata.worldbank.org/index.php/home). Data for labor variable obtained for the year 1968 to 1990 from Penn World Tables (http://www.ggdc.net/pwt.); and from the year 1991 to 2017 from World Bank (http://microdata.worldbank.org/index.php/home). Natural logarithmic transformation was applied to the variables in order to have a more stable data variance. Table 2 below presents the variables under investigation, their definitions, and descriptive statistics.

Table 2. Definition of Variables and Summary Statistics

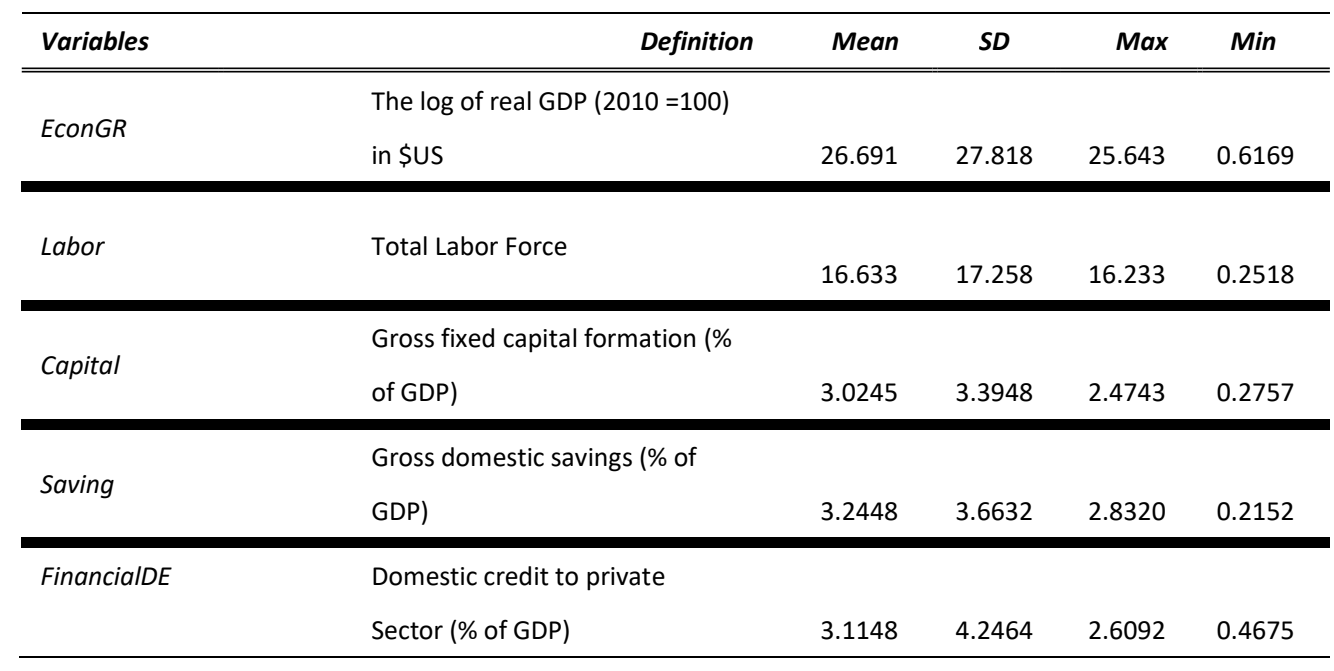

\subsection{The Econometric Model and Methodology}

The long-run elasticities estimate between the regressors and growth in Turkey can be represented in a linear function expressed as:

$$
\ln \text { EconGR }_{t}=f\left(\ln \text { Labor }_{t}, \ln \text { Capital }_{t}, \ln \text { FinancialDE }_{t}, \ln \text { Saving }_{t}\right)
$$

Where $\ln E c o n G R$ represents the natural logarithm of gross domestic product. On the other hand, lnSaving is the natural logarithm of gross domestic saving as a percentage of GDP, and $\ln$ FinancialDE is the natural logarithm of financial development. $\ln L a b o r$ is the natural logarithm of the labor force, and lnCapital is the natural logarithm of gross fixed capital formation as a ratio of the GDP.

The ARDL bounds testing procedure consists of multiple stages: In the first stage, testing the presence of a long-run relationship between the dependent variable and its driving variables as stated by economic theory. In the second stage, the ARDL model is constructed based on the results of stage one. In the third stage, the short-run dynamic is estimated. In view of the benefits of the ARDL approach to cointegration, and our sample size, we specify the following model:

$$
\begin{aligned}
& \Delta(\ln E \operatorname{conGR})_{t}=\beta_{0}+\sum_{i=1}^{q} \beta_{1} \Delta(\ln E \operatorname{conGR})_{t-i}+\sum_{i=0}^{p} \beta_{2} \Delta(\ln \text { Saving })_{t-i}+
\end{aligned}
$$

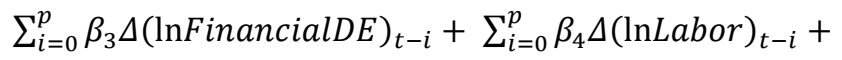

$$
\begin{aligned}
& \sum_{i=0}^{p} \beta_{5} \Delta(\ln \text { Capital })_{t-i}+
\end{aligned}
$$

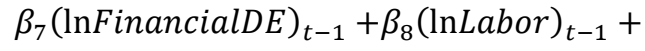

$$
\begin{aligned}
& \beta_{9}(\ln \text { Capital })_{t-1}+\beta_{10}(\ln E \text { conGR })_{t-1}+e_{t}
\end{aligned}
$$$$
\beta_{6}(\ln \text { Saving })_{t-1}+
$$ 
Where, $\Delta$ is the first difference operator, $q$ and $p$ are the optimal lag length. $\beta_{1}, \beta_{2}, \beta_{3} \beta_{4}$, and $\beta_{5}$ represent short- run dynamic coefficients and $\beta_{6}, \beta_{7}, \beta_{8}, \beta_{9}$, and $\beta_{10}$ represent the long-run multipliers of the underlying ARDL model. $\beta_{0}$ is the intercept, and $e_{t}$ represents the white noise error term. Ln is the $\log$ of the variables $\ln$ EconGR, LnLabor, LnCapital, $\ln$ Saving, and $\ln$ FinancialDE.

For the long-run results to be trustworthy, the variables have to be cointegrated. The cointegrating relationship among the variables is tested through the joint significance of the coefficients. The null hypothesis of long-run cointegration $\left(H_{0}=\beta_{6}=\beta_{7}=\beta_{8}=\beta_{9}=\beta_{10}=0\right)$, and the alternative hypothesis implying no cointegration among the variables $\left(H_{\mathrm{a}} \neq \beta_{6} \neq \beta_{7} \neq\right.$ $\beta_{8} \neq \beta_{9} \neq \beta_{10} \neq 0$ ) is tested. The computed F-statistic from equation (2) will be compared with the critical tabulated value (Narayan, 2005).

Before estimating the long-run specification, it is important to determine the lag order through VAR. Once we ascertain the long-run relationship among the variables, we proceed to estimate the short-run dynamic parameter by estimating the error correction model. The error correction model (ECM) is specified as follows:

$$
\begin{aligned}
\Delta(\ln E \text { conGR })_{t}= & \beta_{0}+\sum_{i=1}^{q} \beta_{1} \Delta(\ln E \text { conGR })_{t-i}+\sum_{i=0}^{q} \beta_{2} \Delta(\ln \text { Saving })_{t-i}+\sum_{i=0}^{q} \beta_{3} \Delta(\ln \text { Financial } D E)_{t-i} \\
& +\sum_{i=0}^{q} \beta_{4} \Delta(\ln \text { Labor })_{t-i}+\sum_{i=0}^{q} \beta_{5} \Delta(\ln \text { Capital })_{t-i}+\psi E C T_{\mathrm{t}-1}+e_{t}
\end{aligned}
$$

The $E C T_{\mathrm{t}-1}$ denotes the error correction term or speed of adjustment of convergence towards equilibrium. The sign must be negative and significant to ensure convergence of the dynamics to the long-run equilibrium.

In order to confirm the goodness of fit of the model, numbers of diagnostic tests were conducted. These tests examine the normality, serial correlation, and heteroscedasticity. As recommended by Pesaran et al. (2001), the cumulative sum of the recursive residuals (CUSUM) and the cumulative sum of squared recursive residuals (CUSUMSQ) tests, suggested by Brown et al. (1975) are also used to test a null hypothesis of parameter constancy over the sample period.

\section{The Empirical Results and Discussion}

\subsection{Stationary Test}

The first requirement for employing the ARDL approach is affirming that none of the variables is I(2) to avoid ARDL model crash in the presence of integrated stochastic trend of I(2). Thus, to confirm that none of the series is I(2), the Augmented Dickey-Fuller (ADF) and the PhillipsPerron unit root tests are used and the results are reported in Table 3. 
Table 3. The Results of Unit Root Tests

\begin{tabular}{|c|c|c|c|c|}
\hline \multirow{2}{*}{ Variables } & \multicolumn{2}{|c|}{ Level } & \multicolumn{2}{|c|}{ First Difference } \\
\hline & $A D F$ & $P P$ & $A D F$ & $P P$ \\
\hline \multicolumn{5}{|c|}{ Without Time Trend } \\
\hline Ln EconGR & 0.163111 & 0.178036 & $-6.851000^{* * *}$ & $-6.846762^{* * *}$ \\
\hline Ln Labor & 0.055248 & 0.178329 & $-7.502353^{* * *}$ & $-7.526356^{* * *}$ \\
\hline Ln Capital & -1.780574 & -1.770142 & $-6.598181^{* * *}$ & $-6.639286^{* * *}$ \\
\hline Ln Saving & -2.365818 & -2.238817 & $-9.301975^{* * *}$ & $-9.353133^{* * *}$ \\
\hline Ln FinancialDE & 0.452644 & 0.241465 & $-5.378890^{* * *}$ & $-5.321863^{* * *}$ \\
\hline \multicolumn{5}{|l|}{ With Time Trend } \\
\hline Ln EcoonGR & -2.517542 & -2.669179 & $-6.789659^{* * *}$ & $-6.795540^{* * *}$ \\
\hline Ln Labor & -2.325493 & -2.399109 & $-7.457608^{* * *}$ & $-7.485984^{* * *}$ \\
\hline Ln Capital & -2.881461 & -3.004923 & $-6.557889^{* * *}$ & $-6.595940^{* * *}$ \\
\hline Ln Saving & -2.303729 & -2.141537 & $-9.415142^{* * *}$ & $-9.665056^{* * *}$ \\
\hline Ln FinancialDE & -0.863561 & -0.959400 & $-5.573310^{* * *}$ & $-5.392730^{* * *}$ \\
\hline
\end{tabular}

Notes: $* * *, * *$ and $*$ denote that the nonstationary hypothesis is rejected at the $1 \%, 5 \%$ and $10 \%$ level respectively.

The inference derived from the unit root tests indicates that all variables are stationary at first difference and are non-stationary at level.

Before estimating the ARDL bound test, we need to select the lag length for the equations (2) and (3). It should be noted that there is a divergence of opinion on the most reliable criterion. Although Akaike's Information Criterion (AIC) and Final Prediction Error (FPE) are superior to other criteria in the case of a smaller sample size (sample size 60 and below). When the sample size is 60 and below and not monthly series, FPE is preferred (Liew, 2004; Ivanov and Kilian, 2005). Fortunately, in our case, there is an agreement among the criteria. These results are not reported here owing to space constraints. In fact, 5 of which agreed on a lag length of 1 .

After having the optimal lag length, we further perform the ARDL bound test to examine the long-run relationship between economic growth and its drivers. It should be noted that the preferred ARDL bounds testing approach to cointegration specification chosen is that with intercept and trend.

\subsection{The Results of Long-Run Relationship}

The outcomes of the estimate of long-term relationship among the variables are reported in Table 4. Since the F-statistic exceeds the upper bound values, the null hypothesis of the absence of no level relationship among the variables is rejected at the 1 percent significant level. This indicates that there is a long-run causal relationship among the variables. 
Table 4. Bounds F-test for Cointegration

\begin{tabular}{lllll}
\hline Test Statistic & Value & Sig. level & $I(0)$ & $I(1)$ \\
\hline \hline F-statistic & $5.973^{* * *}$ & $10 \%$ & 3.03 & 4.06 \\
& $5 \%$ & 3.47 & 4.57 \\
& & $1 \%$ & 4.40 & 5.72 \\
\hline \hline \multicolumn{2}{l}{ Notes: (1) Null hypothesis: No levels relationship, (2) ${ }^{* * *}$ Significant at $1 \%$}
\end{tabular}

Having established the existence of cointegration, we progress by estimating the long-run and the short-run ARDL growth model for the study based on Schwartz Bayesian Criteria (SBC).

The estimated long-run coefficients of our ARDL model are presented in Table 5. Results reveal a statistically significant relationship between saving and economic growth. The coefficient value pointed that an increase of 1 percent in saving as a percentage of GDP would lead to an increase of 15 percent in economic growth. This result is in line with the findings of Altuğ, et al. (2008); Karamelikli and Bayar (2015); Zeren and Yusuf (2013); Er et al. (2014). Further, the result in general is consistent with Solow (1956) growth model.

Table 5. The Long-Run Coefficients

\begin{tabular}{lcccc}
\hline \hline Variables & Coefficient Std. Error & t-Statistic & \multirow{2}{*}{ Prob. } \\
\hline \hline Ln Saving & $0.1488^{* * *}$ & 0.0547 & 2.7194 & 0.0095 \\
Ln FinancialDE & $0.0635^{* * *}$ & 0.0217 & 2.9261 & 0.0056 \\
Ln Capital & $0.2908^{* * *}$ & 0.0480 & 6.0559 & 0.0000 \\
Ln Labor & $0.3164^{* *}$ & 0.1365 & 2.3175 & 0.0255 \\
\hline
\end{tabular}

Note: ${ }^{* * *},{ }^{* *},{ }^{*}$ indicate significance at $1 \%, 5 \%$, and $10 \%$.

On the other hand, at a $1 \%$ level of significance, figures in Table 6 show that the coefficient of financial development is statistically significant. This implies that financial development had contributed to economic growth. This result contradicts the findings of Demetriades and Hussein (1996); Ozturk (2008); and Kenza and Eddine (2016). They documented that there is no significant relationship exist between financial development as a percentage of GDP and economic growth. However, the findings are in line with the results of Kar et al. (2011) and Dilek et al. (2016), where they noted that a significant relationship is existed between financial development and economic growth for Turkey.

Similarly, the empirical results show that the coefficient of labor is positive and significant at the 5 percent level. Therefore, an increase in the labor force by 1 percent would increase economic growth by $32 \%$. This indicates that labor input does have a substantial and statistically significant effect on the GDP growth performance. In addition, the results show that capital comes second in influencing Turkish economic growth. Specifically, a 1\% increase in gross fixed capital formation as a percentage of the GDP, would cause the level of economic growth to increase by over $0.29 \%$. Moreover, the coefficient of LnCapital turned to be significant at the 1 percent significant level. This result is in line with the findings of Lains (2003) and Altuğ et al. (2008) which indicate that many developing countries, including some 
high-performers such as the East Asian or South European countries, that capital input is vital to economic growth in Turkey.

\subsection{The Results of Short-Run Relationship}

Turning to the economic growth response of deviations from long-run equilibrium, the shortrun coefficients associated with the long-run were estimated and the results are shown in Table 6. The coefficient of the $E C T_{\mathrm{t}-1}$ is negative and statistically significant at the 1 percent level, providing additional evidence to the cointegrating relationships among the model variables. In fact, the ECM indicated that about 64 percent of the deviations from an equilibrium path arising from the model are restored within a period of one year.

Table 6. The Short-Run Error Correction Estimates

\begin{tabular}{lcccc}
\hline ARDL $(1,1,1,0,0,0)$ & Based on Akaike Information Criteria \\
\hline & & \multicolumn{3}{c}{$t$ - } \\
Variables & Coefficient & Std. Error & Statistic & Prob. \\
\hline \hline D Ln Saving & $0.094913^{* *}$ & 0.039446 & 2.406141 & 0.0207 \\
D Ln FinancialDE & $0.040476^{* * *}$ & 0.013958 & 2.899869 & 0.0060 \\
D Ln Labor & $0.201813^{* *}$ & 0.091957 & 2.194655 & 0.0339 \\
D Ln Capital & $0.268974^{* * *}$ & 0.030746 & 8.748191 & 0.0000 \\
Trend & $12.02399^{* * *}$ & 2.095177 & 5.738889 & 0.0000 \\
Intercept & $0.019793^{* * *}$ & 0.003408 & 5.808549 & 0.0000 \\
ECT(-1) & $-0.637751^{* * *}$ & 0.111392 & -5.725281 & 0.0000 \\
\hline \hline
\end{tabular}

Note: The asterisk denotes rejection ${ }^{* * *} P<0.01, \quad{ }^{* *} P<0.05^{*}, P<0.1$

The results of the above table also show that in the short-run, gross domestic saving have a very significant effect on growth of GDP and a $1 \%$ increase in saving calculated as a percentage to GDP leads to a $9.5 \%$ increase in GDP. Furthermore, the impact of saving to GDP in the short-run is much lower than its effect in long-run.

On the other hand, financial development is positively related to economic growth and this relationship is statistically significant at the 1 percent level. Other things remain the same, a $1 \%$ increase in financial development increases economic growth by 4.0 percent.

The results also show that gross fixed capital formation contributes positively and significantly to economic growth. Keeping all else the same, a $1 \%$ increase in this variable leads to about 27 percent increase in the real GDP. Similarly, a $1 \%$ increase in labor leads to a $20.2 \%$ increase in GDP. This indicates that labor input is the second important contributor to growth of GDP.

In order to check the robustness and the validity of the estimated model, an essential post estimation diagnostic tests were performed. The results of these tests are presented in Table 7. The empirical finding shows normality of the error term. Thus, the null hypothesis of no serial correlation is not rejected. The ARCH test also confirms that the residuals are homoscedastic, suggesting no autoregressive conditional homoscedasticity. The empirical evidence from Jarque-Bera test statistic confirmed the normality behavior of the estimated residual series of the model. 


\section{1) Macrothink}

Table 7. The Results of the Diagnostic Tests

\begin{tabular}{lll}
\hline \hline Normality & Jarque-Bera & $2.08367(0.7583)$ \\
Serial Correlation & Breusch-Godfrey serial correlation LM test & $0.04030(0.8419)$ \\
Heteroscedasticity & ARCH test for Heteroscedasticity & $0.74862(0.6327)$ \\
\hline \hline
\end{tabular}

Furthermore, to examine the structural stability of the model, we conduct the CUSUM and the CUSUMSQ tests as suggested in Brown et al. (1975) to test for parameter stability throughout the sample. Figure 2 and 3 present the plot of the two tests. The results show that both the CUSUM and CUSUMSQ plots lie within the 5\% critical bound; hence, they infer that the parameters of the model do not suffer from any structural instability during the period under review. Thus, the null hypothesis that all coefficients are stable cannot be rejected.

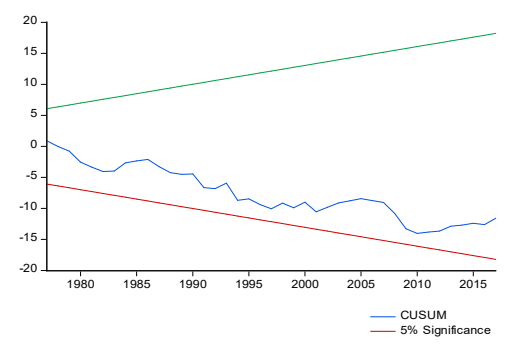

Figure 2. Plot of CUSUM

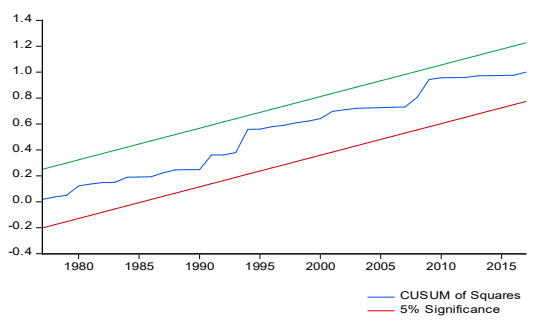

Figure 3. Plot of CUSUMSQ

\section{Conclusion and Policy Implications}

This paper examines the impact of gross domestic saving and financial development on economic growth in Turkey during the period 1968 to 2017. The long-run relationships between economic growth and saving as well as financial development are intriguing and are of acute interest to policy makers.

The long-run coefficients of the natural logarithm of gross domestic saving and financial development are both positive and statistically significant at $1 \%$ percent level implying that these two variables have a significant and positive impact on growth in the long-run. Specifically, a $1 \%$ increment in saving leads to $14.9 \%$ rise in economic growth in the long-run, on average, keeping other things constant. Similarly, a 1\% change in financial development results in $6.35 \%$ change in economic growth in the long-run, on average, ceteris paribus. These results came up with the same conclusion as in Şamiloğlu and Savaş (2010), Zeran and Akbas 
(2013), and Yildiz and Atasaygin (2015) where financial development found to have a positive and significant effect on economic growth in Turkey. Contrary to the findings of Ardic and Damar (2006), and Yucel (2009) where financial development found to have a negative and significant influences on economic growth.

Furthermore, long-run coefficients of capital and labor are both statistically significant. The results suggest, on the long-run, labor input plays the most important role in economic growth process of Turkey. This result is similar to that of Harvie and Pahlavani (2006) in relation to Korea; Akhtar (2006) in relation to Indonesia; Gupta et al. (2017) in relation to India. The second important driver to the growth of the Turkish economy is capital followed by saving and finally financial development.

Similarly, the coefficients of saving and financial development found to have a significant and positive impact on economic growth in Turkey in the short-run. It was also found that the speed of adjustment in the estimated model is high with 64 percent of disequilibrium eliminated within one year.

It is important to state that given this scenario, policy makers should pay keen attention on implementing policies that result in increasing the share of gross domestic saving in GDP. Similarly, fostering the development of a country's financial sector will provide the necessary funds to the productive sector of the economy, which in turn enhances the country's economic growth. In addition, the results elucidated that higher capital formation as well as higher employment were essential for the Turkish economy to achieve a sustained increase in its growth rate.

\section{References}

Akhtar H. (2006). Sources of Economic Growth in Indonesia, 1966-2003. Applied Econometrics and International Development, 6(2), 183-208.

Altuğ G. S., Filiztekin, A., and Pamuk, Ş. (2007). Sources of Long-Term Economic Growth for Turkey, 1880-2005. CEPR Discussion Paper No. 6463. https://doi.org/10.1017/S1361491608002293

Altuğ, G. S., Filiztekin, A., and Pamuk, S. (2008). Sources of Long-Term Economic Growth for Turkey. European Review of Economic History, 12(3), 393-430. https://doi.org/10.1017/S1361491608002293

Ardic, O.P., and Damar, H.E. (2006). Financial Sector Deepening and Economic Growth: Evidence from Turkey. Published in Topics in Middle Eastern and African Economies, 9, 125.

Brown, R. L., Durbin, J., and Evans, J. M. (1975). Techniques for Testing the Constancy of Regression Relationships over time. Journal of the Royal Statistical Society, 37(2), 149-192. https://doi.org/10.1111/j.2517-6161.1975.tb01532.x 
Demetriades, P., and Hussein, K. A. (1996). Does Financial Development Cause Economic Growth? Time Series Evidence from 16 Countries. Journal of Development Economics, 51(2), $387-411$.

Demirhan, B. (2016). Financial Development and Investment Amount Nexus: A Case Study of Turkey. Asian Economic and Financial Review, 6(3), 127-134. https://doi.org/10.18488/journal.aefr/2016.6.3/102.3.127.134

Dilek, D., Ispir, M. S., and Yetkiner, H. (2017). Financial Development and Economic Growth: Some Theory and More Evidence. Journal of Policy Modeling, 39(2), 290-306. https://doi.org/10.1016/j.jpolmod.2016.08.001

Er, H. P., Tugcu, T.C., and Coban, O. (2014). Investigating the Link between Savings, Inflation and Economic Growth: An ARDL Analysis for the Case of Turkey. Journal of Economics, Finance and Accounting, 1(2), 81-90.

Gupta, K., Mallikarjuna, M., and Prabhakara, R. R. (2017). Human Capital, Technology and Economic Growth in India: An ARDL Approach. International Journal of Business Quantitative Economics and Applied Management Research, 3(9), 28 -40.

Güngör, H., Çiftçioğlu, S., and Balcılar, M. (2014). Does Financial Development Increase Private Savings? The Case of Turkey. International Journal of Business and Social Science, 5(2), 36-47.

Harvie, C. and Pahlavani, M. (2006). Sources of Economic Growth in South Korea: An Application of the ARDL Analysis in the Presence of Structural Breaks - 1980-2005.Working paper 06-17. Department of Economics, University of Wollongong.

Ivanov, V., and Kilian, L. (2005). A Practitioner's Guide to Lag Order Selection for VAR Impulse Response Analysis. Studies in Nonlinear Dynamics and Econometrics, 9(1), 1-36. https://doi.org/10.2202/1558-3708.1219

Kar, M., Şaban, N., and Hüseyin, A. (2011). Financial Development and Economic Growth Nexus in the MENA Countries: Bootstrap Panel Granger Causality Analysis. Economic Modelling, 28(1-2), 685-693. https://doi.org/10.1016/j.econmod.2010.05.015

Karamelikli, H., and Bayar, Y. (2015). Remittances and Economic Growth in Turkey. ECOFORUM, 4(2), 33-40.

Kenza, M., and Eddine, G. N. Z. (2016). The Effect of the Financial Sector Development on Growth: The Case of the MENA Countries. Arab Economic and Business Journal, 1(11), 72 85. https://doi.org/10.1016/j.aebj.2016.03.003

Lains, P. (2003). Catching up to the European Core: Portuguese Economic Growth, 1910-1990. Explorations in Economic History, 40(4), 369-386. https://doi.org/10.1016/S00144983(03)00042-1

Levine, R. (1991). Stock Markets, Growth, and Tax Policy. The Journal of Finance, 46(4), 1445-1465. https://doi.org/10.1111/j.1540-6261.1991.tb04625.x 
Lewis, W. A. (1955). The Theory of Economic Growth. Irwin: Homewood, Ill.

Liew, V. K.-S. (2004). Which Lag Length Selection Criteria Should We Employ? Economics Bulletin, 3(33), 1-9.

Lucas, R. E. (1988). On the Mechanics of Economic Development. Journal of monetary Economics, 22(1), 3-42. https://doi.org/10.1016/0304-3932(88)90168-7

Narayan, P. K. (2005). The Saving and Investment Nexus for China: Evidence from

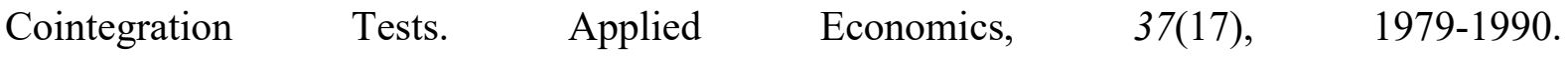
https://doi.org/10.1080/00036840500278103

Ozturk, I. (2008). Financial Development and Economic Growth: Evidence from Turkey. Applied Econometrics and International Development, 8(1), 85-98.

Pesaran, M. H., and Shin, Y. (1998). An autoregressive Distributed-Lag Modelling Approach to Cointegration Analysis. Econometric Society Monographs, 31, 371-413. https://doi.org/10.1017/CCOL0521633230.011

Pesaran, M. H., Shin, Y., and Smith, R. J. (2001). Bounds Testing Approaches to the Analysis of Level Relationship. Journal of Applied Econometrics, 16(3), 289-326. https://doi.org/10.1002/jae.616

Romer, P. M. (1986). Increasing Returns and Long-Run Growth. The Journal of Political Economy, 94(5), 1002-1037. https://doi.org/10.1086/261420

Şamiloğlu, F., and Savaş, B. (2010). Financial Development and Economic Growth in Turkey: An ARDL Bounds Testing Approach. Çankırı Karatekin Üniversitesi Sosyal Bilimler Enstitüsü Dergisi, 1, 25-34.

Solow, R. M. (1956). A Contribution to Economic Growth Theory. The Quarterly Journal of Economics, 70(1), 65-94. https://doi.org/10.2307/1884513

World Bank (2018). World Development Indicators (WDI). The World Bank Group. http://microdata.worldbank.org/index.php/home

Yildiz, H., and Atasaygin, S. (2015). Financial Deepening and Economic Growth: The Turkish Experience. American Journal of Economics, 5(5), 477-483.

Yucel, F. (2009). Causal Relationships between Financial Development, Trade Openness and Economic Growth: The Case of Turkey. Journal of Social Sciences, 5(1), 33-42. https://doi.org/10.3844/jssp.2009.33.42

Zeren, F. and Yusuf, E. A. (2013). Empirical Analysis of the Savings-Growth Nexus in Turkey. Journal of Business, Economics and Finance, 2(3), 67-74. 